\title{
Exchange Rate and Demand for Money in Nigeria
}

\author{
BigBen Chukwuma Ogbonna ${ }^{1, *}$ \\ ${ }^{1}$ Department of Economics, Ebonyi State University, Abakaliki, Nigeria \\ *Correspondence: Department of Economics, Ebonyi State University, Abakaliki, Nigeria. \\ E-mail: bigbenogbonna@yahoo.com
}

Received: March 15, 2015 Accepted: April 24, 2015 Published: June 28, 2015

doi:10.5296/rae.v7i2.7916 URL: http://dx.doi.org/10.5296/rae.v7i2.7916

\begin{abstract}
This study is designed to examine empirically the impact of exchange rate on the stability of demand for money in Nigeria where official and black market exchange rates operate side by side due to exchange controls. Variants of money demand model are estimated using monthly data for the period of 2005-2013. Cointegration and system equation techniques combined with CUSUM and CUSUMSQ tests are employed in the data analysis. Results indicate that in all the variants of the money demand model, coefficients of exchange rates variable (official or black market exchange rates) manifest significant $t$ statistics, meaning that the null hypothesis of restricting the coefficients of exchange rates in money demand model in Nigeria is rejected for each variant. This suggests that coefficient of exchange rates variable (OMEXR or BMEXR) belongs to the cointegrating space in all the instances. Judging from the freakiness of the coefficients of the variants of the money demand function and the results of the tests for stability of the models combined, the most appropriate demand for money function for Nigeria appear to be the one that includes M1, the interest rate, inflation rate, and official exchange rate. This implies that in Nigeria, a greater percentage of the foreign exchange demand may be public sector driven and substantial percentage of the private sector foreign exchange needs is sourced from the official exchange rate market due to the substantial disparity between the two rates. This may mean consumers' easy access to official exchange rate and transparency in the operation of official exchange rate market in Nigeria.
\end{abstract}

Keywords: Demand for money, Black Market Exchange Rate, Co-integration 


\section{Introduction}

The design of incorporating exchange rate as one of the determinants of money demand in modeling money demand function was initiated by Robert Mundell (1963). Other studies that subsequently made attempts at examining such association empirically include, Domowitz and Elbadawi, 1987; Arize, 1989 Hassan, 1992; and Pozo and Wheeler, 2000 amongst others. Several other studies on the demand for money have included official exchange rate in the money demand function (see, Arrango and Nadiri, 1981; Bahmani-Oskooee and Pourheydrian, 1990; Chowdhury, 1997; and Pozo and Wheeler, 2000, McNown and Wallace (1992), Arize and Schwiff (1993) and Bahmani-Oskooee and Rhee (1994).

At the instance of available literature, it appears that little attention has been paid to analyzing the impact of the black market exchange rate on the long-run demand for money in developing countries that operate a dual exchange rate regime. The few spotted include, Hassan et al., 1995; Bahmani-Oskooee, 1996; Arize and Shwiff, 1998 and Tabesh, 2000. This study demonstrates the relevance of black market exchange rate rather than the official rate in the objective modeling of money demand function in developing economies. We do this putting into perspective Nigeria data on a monthly basis for the period of $2002-2012$. The choice of monthly data was informed by the fact that exchange rate market in Nigeria operates at weekly interval. Within the relevant period; there was always a black market for foreign currencies, dominated in the U.S. dollar.

The general consensus in the literature is that in developed countries, nominal exchange rate represents a suitable cost of holding money, whereas in developing countries, due to lack of well developed financial markets, the cost of holding money is often proxied by the expected rate of inflation (Abdelnacer, Abdelhak \& Maliki, 2013). The main purpose of this paper is to examine empirically the impact of the black market or official market exchange rates on the demand for money function in Nigeria. The remaining sections of this paper are structured as follows: Section 2 outlines the brief review of related literature; section 3 provides the methodology, section 4 presents the empirical results and section 5 presents summary of findings and conclusions.

\section{Brief Review of Related Literature}

In this section we review scholarly articles, books and other sources relevant to the subject matter of this study, providing a description, summary, and critical evaluation of each work with a view to evaluating significant literature published on the identified research problem.

Doguwa, Olowofeso, Uyaebo, Adamu \& Bada (2014) in their paper titled, Structural breaks, cointegration and demand for money in Nigeria, estimated the money demand function for Nigeria in the aftermath of the recent global financial crisis and examines whether its underlying properties has changed over the years. In particular, they sort to establish the existence or otherwise of a stable long-run demand for money function for the period of 1991-2013 using quarterly data for Nigeria, while accounting for the possibility of structural breaks. Using the Gregory-Hansen residual based test for cointegration, the study detected the 
existence of both intercept and regime shifts in 2007:Q1 as the null hypothesis of no cointegration was rejected at 1 percent level of significance. This suggests that there exists a run relationship between real money supply, real income, real monetary policy rate, exchange rate spread and movements in exchange rate in Nigeria. The estimation method was assessed to be robust to structural break, which provided evidence of no biasness of the estimated parameters. They confirmed the stability of the money demand function as evidenced by the CUSUMSQ test. The paper concluded that with the long run steady state association established among the variables, the estimated money demand model would provide an important foundation for monetary policy setting in Nigeria.

Nwafor (2014) deployed a non-traditional model of exchange rate behavior, known as Pinto model, to investigate the association between parallel exchange rate, which is assumed to reflect market fundamental, and its determinants within the confines of a reduced-form linear stochastic model, with recourse to the Nigerian naira and the U.S. dollar for the period of 1980-2012. This Pinto model hypothesizes a parallel rate that is assumed to reflect market fundamentals and influenced by such exogenous variables as inflation rate, broad money supply, terms of trade, the official naira dollar exchange rate as a policy variable, and the level of fiscal deficits. Applying the co-integration estimation procedure, the results indicate a long run co-integrating vector between the naira-dollar parallel exchange rate and its aforementioned determinants, meaning that black market exchange rate should be should not be restricted in monetary policy decisions in Nigeria.

In Algeria, dual exchange rates (official and black) coexisted and operated simultaneously due to government restrictions and controls on foreign exchange during the period under review. It is to this extent that Abdelnacer, Abdelhak \& Maliki (2013) examined empirically, the effects of black market exchange rate on the demand for money in Algeria, using quarterly data for the period of 1974-2005 and an ARDL approach combined with CUSUM and CUSUMSQ estimations. Results obtained provided further evidence in favor of including black market exchange rate rather than the official rate for appropriate modeling of money demand functions in Algeria. The study provides further evidence of the relevance of the black market exchange rate as another determinant of the demand for money in less developed countries. The results suggest that M1 is the right monetary aggregate to be considered for effective monetary policy formulation. Analyzing the results further, shed some light on the importance of black market exchange rate, which has a strong impact on the money demand function in Algeria. Following from the results of the unit root tests which indicated mutual integration level of 1(1) for all the variables, we have some reservations for the deployment of ARDL in the data analysis. This is because the use of ARDL technique is advised in two basic conditions as follows: (i) it is best advised for bivariate models, as VAR techniques is considered more appropriate for multivariate models. (ii) the integration levels of the two variables in the bivariate models must not be mutual and any integration level in excess of unit root shall not be applicable.

In the same vein, Dagher \& Kovanen (2011) using the autoregressive distributed lag $(A R D L)$ and bound testing approach to cointegration on quarterly data for 8 emerging economies, investigated the performance of money demand in the wake of short-run oscillations in the 
foreign exchange black market premium. They examined the long-run demand for money on the assumption that exchange rates provide a measure of the cost of holding money. The study proposed a new method of testing for the credibility of economic policies designed and implemented by authorities in the countries of interest. To this effect, the study suggested the substitution of black market premium for exchange rate in the money demand function, and estimating same in its error correction variety.

Dagher \& Kovanen (2011) adopted bounds testing approach developed by Pesaran et al. (2001) to test for the stability of the long-run money demand function for Ghana. The results obtained revealed that despite considerable volatility in the data, money demand function in Ghana was found to remain stable for the period under review and that the key determinants of money demand remained real income and exchange rate in Ghana, with other financial variables identified as insignificant in the estimation. The importance of the exchange rate for money demand in Ghana is consistent with other studies for developing countries and points to the importance of currency substitution and valuation effects. The identification of interest rate as statistically significant in the estimated money demand model provides an insight to the fact that that financial markets are yet to play an important role in the public's financial decisions. Finally, they examined the stability of long-run coefficients using the CUSUM and CUSUM squares tests and the stability of the estimated money demand equation was confirmed since the test statistics remain within their critical values at 5 percent marginal significance level.

Mundell's conjecture in 1963 that the demand for money could depend on the exchange rate in addition to income and interest rate has received some attention in the literature by including the official exchange rate and estimating the money demand in a few developed countries. In less developed countries, since there is a black market for foreign exchange resulting from the control and regulation of such market, it has been suggested that the black market exchange rate rather than the official rate should be the determinant of the demand for money in LDCs. This proposition is tested by Bahmani - Oskooee \& Tanku (2006) using economic data for less developed countries estimated the demand for money for 25 LDCs employing the bounds testing approach to cointegration. The main conclusion is that while in some LDCs, the black market rate enters into the formulation of the demand for money, in some others the official rate is the determinant. The black market premium also played a role in some countries. These mixed results have made it imperative and displayed the need for individual country investigations of this phenomenon with the view of harvesting country specifics into the results.

Little attention has been paid to analyze the impact of black market exchange rate on the demand for money in developing countries that have black market activities for their currencies. It is in this context that Rehman \& Afzal (2003) commission a study to examine empirically the impact of black market exchange rate on the demand for money in Pakistan where official and black market exchange rates operate side by side due to exchange controls. After incorporating black market exchange rate as one of the determinants of money demand function, it is estimated using quarterly data over 1972-2000 periods. Employing ARDL approach combined with CUSUM and CUSUMSQ tests, the results show that M2 not M1 is 
cointegrated with income, inflation rate and black market exchange rate and the estimation relation is also stable for M2.

Andoh \& Chappell (2002) using appropriate empirical measures estimated the demand for money (M2) in Ghana for the period 1960 to 1996. The objective of the study was to test the hypothesis, that Ghana's different macroeconomic adjustment policies in the forms of privatization, exchange rate liberalization amongst others which began in the mid 1980s would alter the demand for money function. The results of the study clearly indicated the existence of a structural break in the demand for money function in 1983. This suggests the reforms in the financial sector calls for of the country's monetary policies and the structure of money demand modeling.

Bahmani-Oskooee (1996) Using the Johansen-Juselius cointegration analysis and exclusion test, this paper demonstrates that in a country where there is a black market for foreign currencies, it is the black market exchange rate and not the official rate that should enter into the formulation of the demand for money. Iranian data over 1959-1990 period are employed to demonstrate this point.

Biswas \& Nandi (1985) the main purpose of this paper is to test the monetarist proposition that disequilibrium in the domestic money market will have a spillover effect on the exchange rate of the country. Since India is a fixed exchange rate regime. The black market exchange rate can be taken as a proxy of free exchange rate. From the result, it is obvious that the monetarist proposition holds for the case of India to a significant extent. When the official exchange rate becomes flexible, as has been the case in India since 1971, this flexibility absorbs some shock of the domestic monetary disequilibrium. The black market exchange rate is supposed to fluctuate less and the gap between the two exchange rates should be narrowed down. The policy prescription that emerges from this paper is that the government should be cautious enough regarding the growth of domestic credit component of the monetary base. Any lack of control on the growth of domestic credit component will result in the loss of precious foreign exchange as the increasing gap between the black market exchange rate and the official rate will induce remittances of foreign currency through the unofficial channel.

From the early period of 1970s, monetary approach to exchange rate determination has dominated explanation of exchange rate behavior. In the monetarist framework, exchange rate may be defined as the Price for which the currency of a country can be exchanged for another country's currency. Exchange rate of any domestic currency may be influenced by interest rates, inflation rate, trade balance, political stability, internal harmony, level of transparency in the conduct of government business amongst others. On the other hand As such, the domestic money stock should influence the black market exchange rate. The relationship between the domestic stock of money and the black market exchange rate has been seen as a two-way relationship in the case of exchange control economies.

Works by Blejer (1978a, b) on the association between exchange rate and money stock suggest a sort of bi-directional causality, meaning that expectations about the future developments in black market exchange rate market appeared to influence the domestic 
demand for money, while in the reverse order, developments in money supply in the domestic economy appear to have influenced the exchange rate in the black market. The results of Blejer (1978 b) suggest that in the event of any regime of exchange control, prospect of a black market depreciation of exchange rate, would result in significant reduction in demand for money. Put the other way, if the expected return from holding foreign currency assets increases, meaning that the opportunity cost of holding domestic money increases, individuals would tend to substitute domestic assets for foreign ones leading to a reduction in the demand for domestic cash balances.

Furthermore, (Frenkel 1976; Dornbusch 1976; Mussa 1976) observed the following implication of the above scenario: (i) government intervention in the black market exchange rate will have consequence in the domestic demand for money, and this may obscure the effects of any stabilization policies in the money market. (ii) That in the reversed aspect of the interrelationship between developments in the domestic money supply and the variations in the autonomous market exchange rate is in line with the broad monetarist tradition in which monetary variables are supposed to influence exchange rate behavior. For (Friedman 1953; Mussa 1976), in an exchange control regime, where the official · exchange rate is fixed, any disequilibrium in the domestic money market in the form of an excess supply of money is expected to have a spillover effect on both balance of payment and exchange rate variation.

In the monetarist tradition, Blejer as shown above has used the demand for money function in which the interest rate has not been incorporated as an argument. But the diversion of foreign exchange from the official market to the black market depends on two types of margin of choice of between money and goods, and between money and bonds. The first is relevant for the goods market while the second is relevant for the capital market. Blejer in his study laid emphasize on the goods market because according to him, he used inflation predominant countries in testing his model. Although Bejer may be correct within the context of his study, the consideration of capital market is important for two reasons. First, in the absence of information about illegal trade across national boundaries, the latter is not incorporated in the model. Second, on the assumption of free movement of capital in the international market, the public diverts a portion of officially allocated foreign exchange to earn a profit (round tripping). The latter depends on the difference between the domestic nominal interest rate and that of the foreign country. Based on the above argument, it is imperative that we should retain the interest rate in the demand for money function. Accordingly, the monetarist model used by Blejer is modified in the present study to incorporate interest rate variable. Furthermore, little attention has been paid to analyzing the impact of black market exchange rate on the demand for money in developing countries in general and in Nigeria in particular. To this extent we commission this study to add to the economic literature of Nigeria.

\section{Methodology}

This study is using what already exist to reflect backwards with the view of explaining why. To this extent, the study seeks to establish the relationship between official and black market exchange rates using separate money demand functions putting into perspective Nigeria 
economy. To achieve these fits, we opted to deploy the relevant variables as follows: M1 and M2 as the explained variables, and official and black market exchange rates (OMEXR and BMEXR), interest rates (INTR) and inflation rates (INFR) for explanatory variables. M1 means narrow money stock and M2 means broad money stock, INTR means cost of capital in percentage, while INFR means inflation rate in percentage points. Monthly data for the periods of February 2005 to December, 2013 are sourced from the IMF-Statistical bulletin On-line; 2013.The paper employs co-integration procedure and vector error correction modeling, to investigate the effect of exchange rate variation on money market activities in Nigeria. The latest analytical econometric application software package such as E-View 7.0 was frequently used in the study.

\subsection{Model Specification}

In developing countries, due to lack of well developed financial markets, rather than using the interest rate as the opportunity cost of holding money, researchers have often proxied it with the rate of inflation. For the purpose of accommodating both goods and capital markets, we have to include both inflation and interest rates in the model. Income is replaced with inflation rates since inflation and income appear to have the same effects on demand for money stock. Considering the current level of financial and stock market development in Nigeria, it would be a misfit to model the effect of exchange rate on the demand for money in the absence of interest rates as control variables. To this extent, the modeling approach in this study abstracts from Bahmani-Oskooee (1996) with some modifications. The adjustments involve dropping of income variable and introduction of interest rates. There two reasons to justify the modifications. First, considering the current level of financial and stock market development in Nigeria, it would be a misfit to model the effect of exchange rate on the demand for money in the absence of interest rates as control variables. Second, with the monthly frequency of the variables, we experienced the non availability of the income variable as proxied with GDP at the monthly frequency. Therefore; the money demand function that we employ to estimate for Nigeria takes the following form.

$$
\log M_{\mathrm{t}}=\alpha+\prod \mathrm{INFR}_{\mathrm{t}}+\lambda \mathrm{INTR}_{\mathrm{t}}+\Psi \log E X R_{\mathrm{t}}+\mu_{\mathrm{t}}
$$

,where $M$ is the demand for cash balances; INFR is the inflation rate proxied with percentage change in the consumer price index, INTR is the domestic interest rate and EXR is the exchange rate defined as the number of Nigerian Naira per U.S. dollar. Depending on whether the monetary aggregate is defined as M1 or M2, and the exchange rate as official $(O M E X R)$ or black market rate $(B M E X R)$, variants of Equation (1) are subjected to empirical analysis. In line with a priori expectations, while an estimate of $\Pi$ is expected to be negative $(\Pi<0)$, an estimate of $\lambda$ is expected to be negative $(\lambda<0)$ and an estimate of $\Psi$ is equally expected to be negative $(\Psi<0)$ within the period under review. The objective of this study is to estimate the long-run exchange rate, interest rate and inflation rate dynamics of M1 and M2 monetary aggregate as expressed in equation (1) above and examine their stability using the co-integration approach. On identification of co-integrating equation, we employ Akaike Information Criteria (AIC) to determine the appropriate lag length of 12 lags. Then Vector Error Correction Model (VECM) is specified and estimated using monthly data on Nigeria 
for the period 2004M01 - 2013M12.

\section{Empirical Results}

This section subjects the variants of Equation (1) to empirical analysis, using Nigerian monthly data for the period 2004MO1 - 2013M12. With recourse to extant developments in the econometrics literature, the paper employs Johansen-Juselius (1990) co-integration procedure, vector error correction modeling and system equation approach, to investigate the effect of exchange rate variation on demand for money in Nigeria.

An implicit assumptions that underlie regression analysis involving time series data is that such a data series is stationary (Gujarati, 1995). In this context, testing for stationary or otherwise of the employed data sets becomes of essence in these analyses to stem the problem of spurious regression. In effect, the time series properties of the data set used in estimation of equation (1) need to be identified. The stationary property of each variable is verified using Augmented Dickey-Fuller (Dickey and Fuller, 1979). The results of $A D F$ show that at $95 \%$ level of significance, all the variables are confirmed to have unit root, meaning that all the variables used in the modeling become stationary after one period lag.

\subsection{Tests for Co-integration}

With the manifestation of unit root 1(1) by variables of interest, which is a precondition for the existence of a long run association between dependent and independent variables, we are now in a position to apply the Johansen-Juselius (1990) cointegration technique. This analysis generates two likelihood ratio tests, known as trace tests and maximum eigenvalue to determine the number of cointegrating vectors using the maximum-likelihood estimation procedure. The results of the trace and the maximum eigenvalue tests for cointegration ranks for all the variants of equation one not reported here but available from the author upon request indicate one cointegrating vector each.

Table 1. Normalized Cointegration Coefficient for Variants Money Demand Equations

\begin{tabular}{ccccccc}
\hline scenario & Log M1 & LogM2 & LBMEXR & LOMEXR & INTR & INFR \\
\hline 1 & -1.00 & - & -0.00154 & - & -0.00351 & 0.00368 \\
& & & $(-22.84)$ & & $(-2.02)$ & $(8.088)$ \\
2 & -1.00 & - & - & -0.00152 & -0.00788 & 0.3210 \\
& & & & $(11.87)$ & $(-3.21)$ & $(5.92)$ \\
& - & & & & & \\
3 & & -1.00 & -0.00328 & - & -0.00453 & 0.00595 \\
& & & $(-43.58)$ & & $(2.80)$ & $(11.74)$ \\
4 & & -1.00 & - & -0.002920 & -0.00025 & 0.00679 \\
& & & & $(-4.15)$ & $(-3.27)$ & $(4.03)$ \\
\hline
\end{tabular}

Note: 1. Numbers inside the brackets are the t statistics.

2. For all variants of the equation, the degree of freedom is $n-k(107-4)=103 d f$.

3. The critical value is set at the $1 \%$ level of significance for all variants of the equation

4. $t_{\text {crit }}=2.660$ for all the variants of the equation 
To this extent, establish if all the variables in each scenario really belong to co-integrating space because the convergence toward a long-run equilibrium in each scenario could be due to a strong relation among some and not all of the variables. In order to identify which variable(s) should enter the co-integrating space and which should be excluded from the co-integrating space, we apply the $t$ test on the long run coefficients of the cointegrating equations to gauge their freakiness and level of significance in each variant of the money demand model.

First, we report all possible cointegrating vectors in each scenario. Second, we normalize all models on the monetary aggregate M1 or M2 by setting their coefficients at -1 . From Table 1 above, the null hypothesis of restricting the coefficient of the official exchange rate $(O M E X R)$ to zero in models 2 and 4 (M1 and M2 money demand functions respectively) can be rejected, as the t-statistcs of the coefficients official market exchange rate (OMEXR) for M1 and M2 models of 11.8 and -4.15 respectively are greater than the critical value 2.660 at 1 percent level of significance with 103 degree of freedom. This indicates that the coefficients of $(O M E X R)$ in models 2 and 4 are statistically significant. However, in models 1 and 3 where the black market exchange rate has entered into the M1 and M2 functions, the null hypothesis of restricting the coefficient of BMEXR to zero is equally rejected. Excepting for model 1(MI demand) where the coefficient of interest rate can be restricted, the rest of the variables belong to or enter the cointegrating space with their coefficients statistically significant. Judging from the freakiness of the coefficients of the variants of the money demand function and the results of the CUSUM and CUSUMSQ tests for the stability of the models combined, the most appropriate formulation of the demand for money function in Nigeria appear to be the one that includes M1, official exchange rate, the interest rate and inflation rate. This contradicts the finding of Rehman \& Afzal, 2003 for Pakstan and Bahmani-Oskooee, 1996 for Iran and Abdelnacer, Abdelhak \& Maliki, 2013, for Algeria, where black market exchange rates were found to be the best fit into the M2 demand function; and Kabir et al, 1995 for Nigeria who failed to identify exchange rate as a significant variable in the money demand function of Nigeria.

This implies that in Nigeria, a greater percentage of the foreign exchange demands are public sector driven and substantial percentage of the private sector foreign exchange needs is sourced from the official exchange rate market. The significant disparity existing between the official and black market exchange rates in Nigeria must have accounted for such private sector decision. This suggest that whether the official exchange rate or black market exchange rate will fit best into the money demand model of an economy may be a further function of the degree or extent or magnitude of the disparity between the two rates. This equally indicates easy access to foreign exchange by the consumers and transparency in the operation of official exchange rate market in Nigeria.

In scenarios $3 \& 4$ for BMEXR and OMEXR in M2 models respectively, the coefficients of exchange rate variables are found to be negatively signed. These suggest that as the domestic currency (the Nigerian Naira) depreciates, demand for broad money (M2) will decrease. The results further indicate that in scenarios $1 \& 2$ for BMEXR and OMEXR in M1 models respectively, the coefficients of exchange rate variables are found to be negative. These 
suggest that as the domestic currency (NGN) depreciates, demand for narrow money (M1) will decrease. This suggests that the wealth effect argument does not hold for Nigeria, contradicting the findings of Bahmani-Oskooee (1996) where the reverse was the case for Iran.

The positively signed coefficient of inflation rate indicates that among the motives for demanding money balance in Nigeria, transactional motive dominates. This scenario further suggests that the income effect which is absent from the models, due to the non availability of monthly data on income, is substantially accommodated and captured in the inflation effect.

Scenario 3 should have provided the best money demand equation for Nigeria judging from the magnitude of the $t$ statistics of the coefficients of the explanatory variables, but in the CUSUMSQ test for model stability, the recursive line strayed out of the critical value lines, suggesting the absence of stability among the variables of the model (see figure 6 in the appendix). This casts doubts of reliability on the estimation outputs as a basis for credible and informed policy decisions.

\section{Summary and Conclusion}

The main objective of this paper is to explore the significance of exchange rate variable in the money demand function in Nigeria where official and black market exchange rates operate side by side due to exchange controls. We applied the Johansen's cointegration and vector error correction model (VECM) techniques to estimate variants of the money demand model using Nigeria monthly data for the period of 2005 - 2013. The long run coefficients of variants of money demand function were tested for significance to determine the restrictability of exchange rates from money demand model in Nigeria. The results indicate that in all the variants of the money demand model, coefficients of exchange rate variables (official and black market exchange rates) manifest significant $t$ statistics, meaning that the null hypothesis of restricting the coefficients of exchange rates is rejected for each variant. This suggests that coefficient of exchange rates belongs to the cointegrating space in all the instances. Excepting for model 1 in table 1 where interest rate coefficient can be restricted, all the coefficients of the variables belong to or enter the cointegrating space in their various models as specified in table 1 above. Judging from the freakiness of the coefficients of the variants of the money demand function and the results of the CUSUM and CUSUMSQ tests for the stability of the models combined, the most appropriate formulation of the demand for money function for Nigeria appear to be the one that includes M2, the interest rate and inflation rate, and official exchange rate as its arguments. To this extent, the monetary authority should develop and maintain such exchange rate policies that will ensure transparency in official exchange rate activities as will guarantee unhindered access for foreign exchange consumers, as stability in official exchange market will foster stability in the money market in Nigeria. 


\section{References}

Abdelnacer, B., Abdelhak, B., \& Maliki, B. (2013). The black market exchange rate and demand for money in Algeria. International Journal of Arts and Commerce, 2(10), 71 - 82.

Altin, T. (2011). Another view of money demand and black market premium relationship: what can they say about credibility? Bank of Albania

Andoh, S. K., \& Chappell, D. (2002). Stability of the money demand function: evidence from

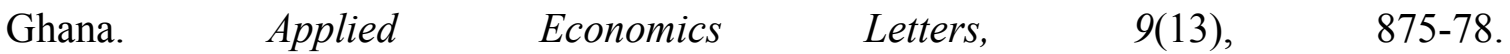
DOI:10.1080/13504850210158971 0.23 Impact Factor.

Arize, A. (1989). An econometric investigation of money demand behaviour in four Asian developing countries. International Economic Journal, 3(4), 79- 93.

Arize, A.C., \& Shwiff, S.S. (1998a). The black market exchange rate and demand for Money in 16 Developing Countries. International Advances in Economic Research, 4, 128-143.

Bahmani-Oskooee, M. (1996). The Black Market Exchange Rate and the Demand for Money in 16 Developing Countries. International Advances in Economic Research, 4, 128-143.

Bahmani-Oskooee, M. (1997). The black market exchange rate and demand for money in Iran. Journal of Macroeconomics, 18(1), 171-176.

Bahmani-Oskooee, M., \& Tanku, A. (2006). Black market exchange rate, currency substitution and the demand for money in LDCs. Economic Systems, 30(3), 249 - 263.

Biswas, B., \& Nandi, S. (1985). The black market exchange rate in a developing economy: The case of India. Study Paper, 85-21

Bleger, M. L. (1978a). Exchange restrictions and the monetary approach to the exchange rate. In The economics of exchange rates: Selected studies, edited by J. A. Frenkel and H. G. Johnson, 117-28. Reading: Addison- Wesley Series in Economics.

Blejer, M. L. (1978b). Black-market exchange rate expectations and the domestic demand for money: Some empirical results. Journal of Monetary Economics, 4, 767-73.

Dagher, J., \& Kovanen, A. (2011). On the stability of money demand in Ghana: a bounds testing approach. IMF Working Paper, WP/11/273, 1-19.

Dickey, D.A., \& Fuller, W.A. (1979). Distribution of estimators for autoregressive time series with a unit root. Journal of American Statistical Association, 74, 427 - 431.

Doguwa, S, I., Olowofeso, O. E., Uyaebo, S. O. U., Adamu, I., \& A. S. Baba. (2014). Structural breaks, cointegration and demand for money in Nigeria. CBN Journal of Applied Statistics, 5(1), 15- 33.

Domowitz, I., \& I. Elbadawi. (1987). An error correction approach to money demand: The Engle, R.F., \& C.W.J. Granger. 1987. "Co-integration and error correction: representation, estimation, and testing. Econometrica, 55, 251-276. 
Dornbush, R. (1976). The theory of flexible exchange rates regimes and macroeconomic policy. Scandinavian Journal of Economics, 78, 255- 75.

Engle, R.F., \& C.W.J. Granger. (1987). Co-integration and error correction: representation, estimation, and testing. Econometrica, 55, 251-276.

Frenkel, J. A. (1976). Adjustments mechanism and the monetary approach to the balance of payments. In Recent issues in international monetary economics, edited by E. Claasen and P. Salin. Amsterdam: North- Holland Publishing Company

Friedman, M. (1953). The case of flexible exchange rates. In Essays in positive economics, 157-203. Chicago: University of Chicago Press

Hassan K.M., Choudhury, A.R., \& Waheeduzzaman, M. (1995). On Black Market Exchange Rate and Demand for Money in Developing Countries: The Case of Nigeria. Atlantic Economic Journal, 23.

Mundell, R.A. (1963). Capital mobility and stabilization policy under fixed and flexible exchange rates. Can. J. Econ. Pol. Sci, 29, 475-485.

Mussa, Michael. (1976). The exchange rate, the balance of payments, and monetary and fiscal policy under a regime of controlled floating. Scandinavian Journal of Economics $78,229-48$

Nwafor, F. C. (2014). Examining the behavior of exchange rate in Nigeria: an application of the Pinto Model. Journal of Economics and Sustainable Development www.iiste.org ISSN 2222-1700 (Paper) ISSN 2222- 2855 (Online) 5 (15) 2014188

Pozo, Susan \& Mark Wheeler (2000). Exchange-rate uncertainty and dollarization: A structural vector error correction approach to estimating money demand. Applied Financial Economics, 10, 685-692.

Rehman, H., \& Afzal, M. (2003). The black market exchange rate and stability of demand for money in Pakistan: A cointegration analysis. Pakistan Economic and Social Review, $X L I(1 \& 2), 13-28$

Tanku, A. (2011). Another view of money demand and black market premium relationship: What can they say about credibility? Bank of Greece Eurosystem Special Conference Paper. 


\section{Appendix}

Figure 1: CUSUM Test for Model Stability for Scenario 1

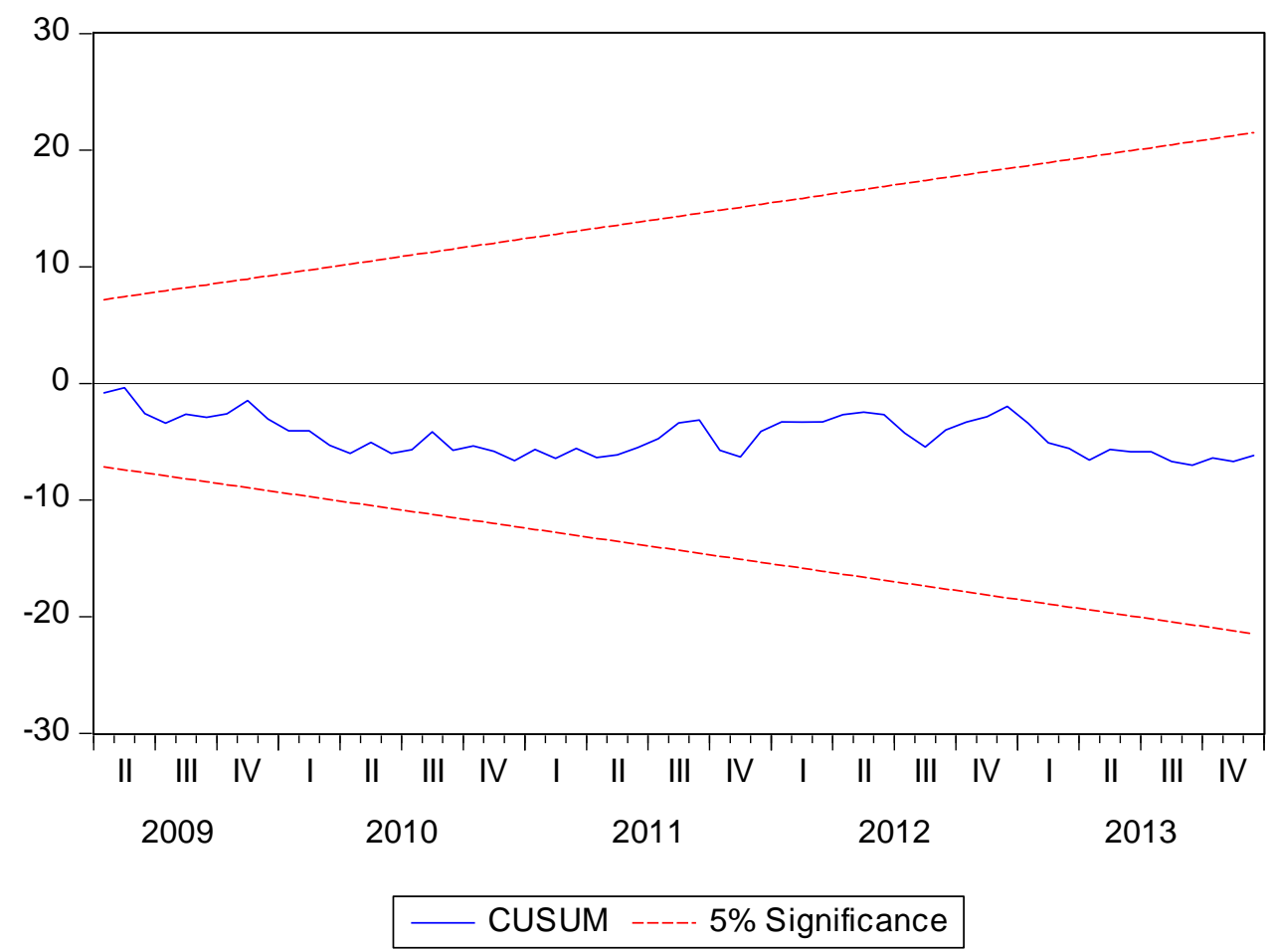

Figure 2: CUSUMSQ Test for Model Stability for Scenario 1

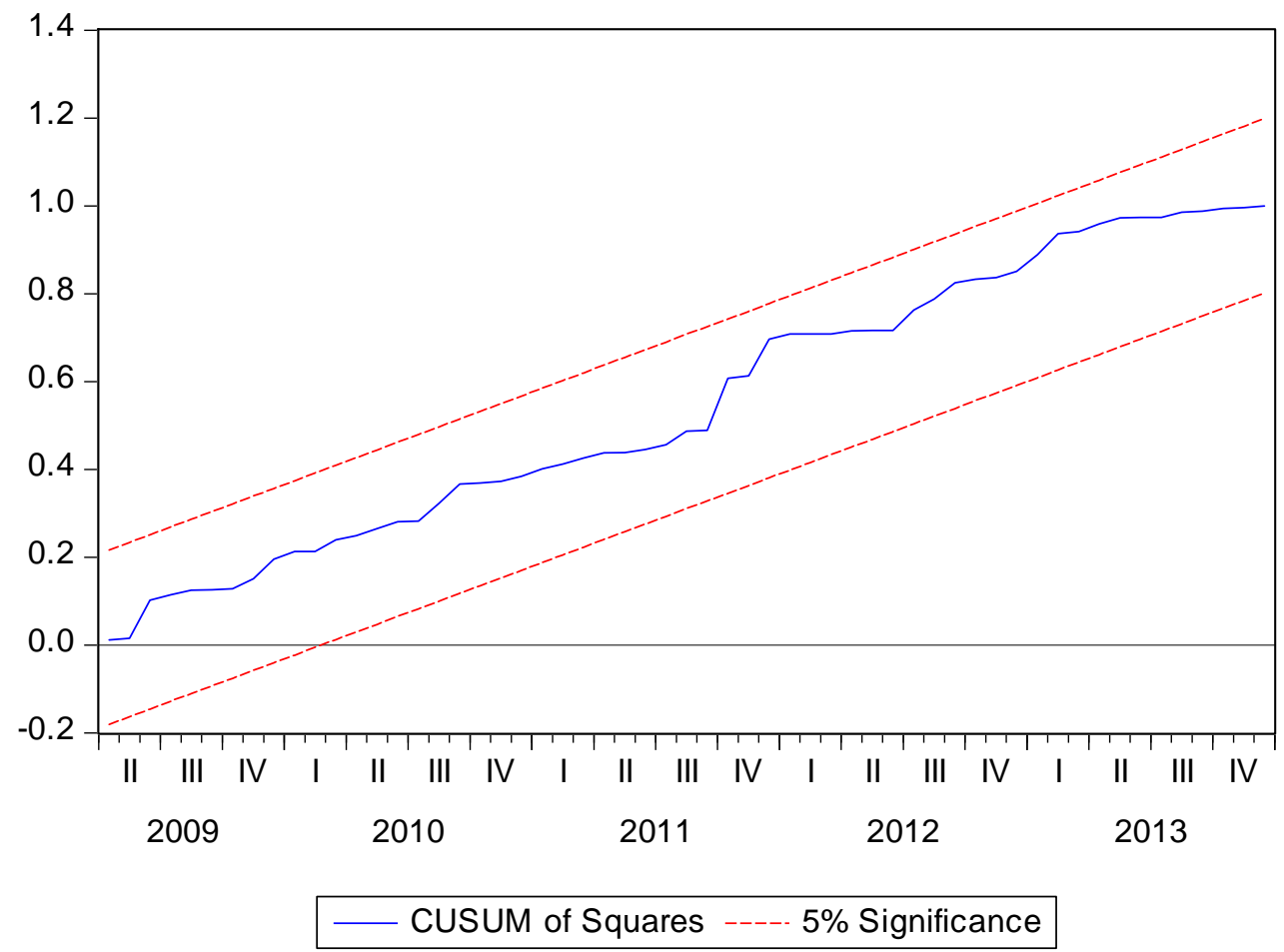


Figure 3: CUSUM Test for Model Stability for Scenario 2

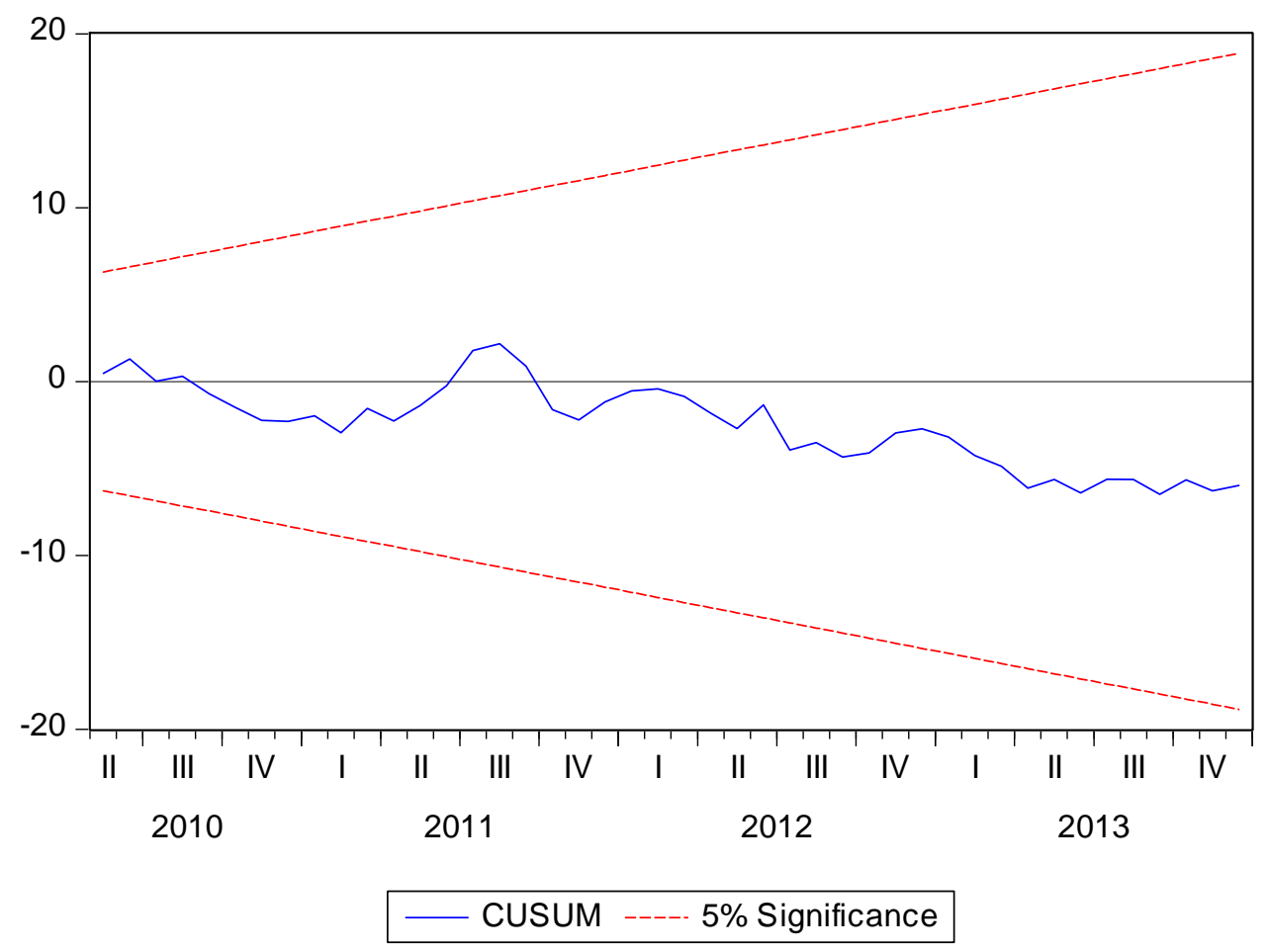

Figure 4: CUSUMSQ Test for Model Stability for Scenario 2

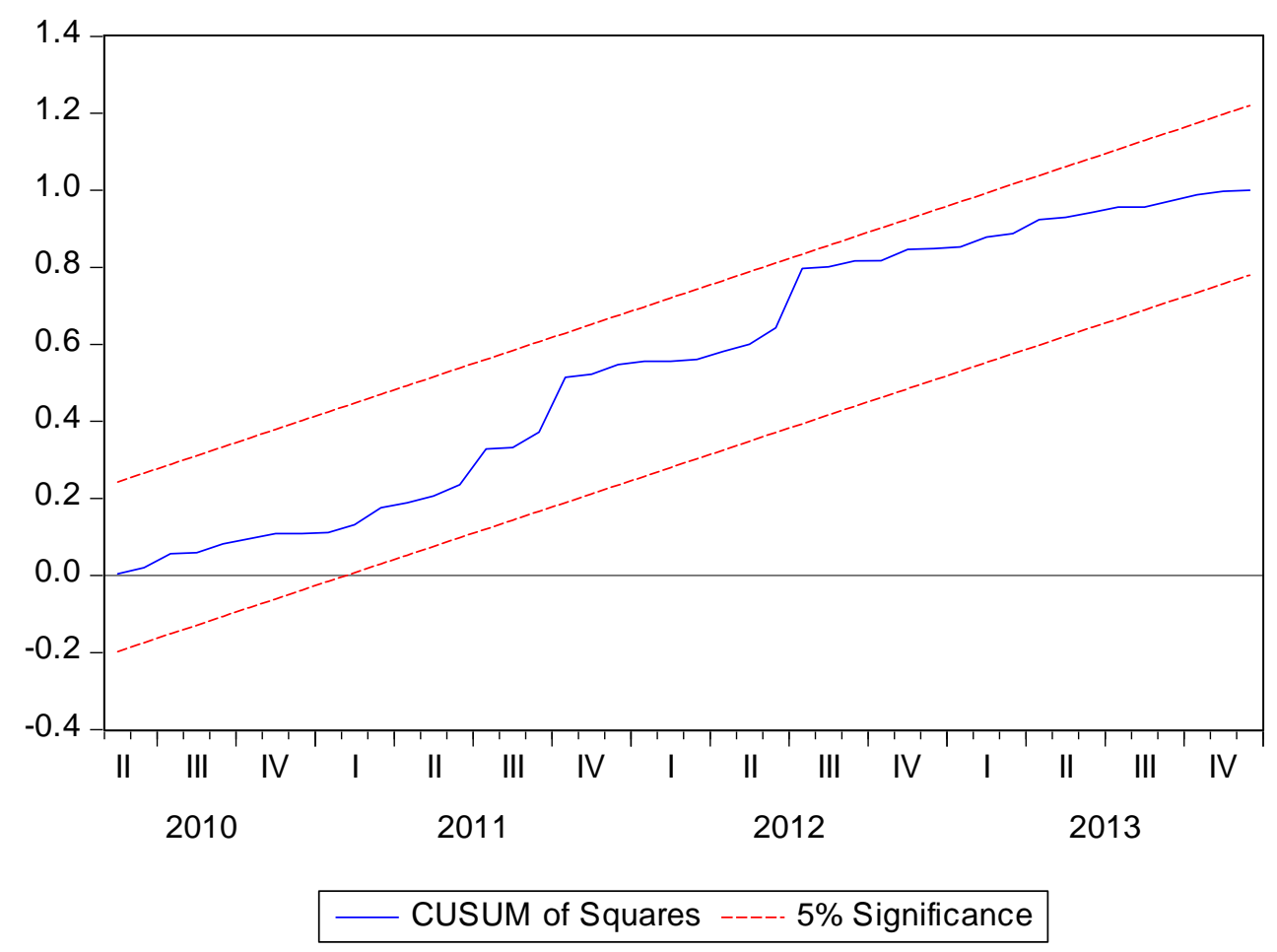


Figure 5: CUSUM Test for Model Stability for Scenario 3

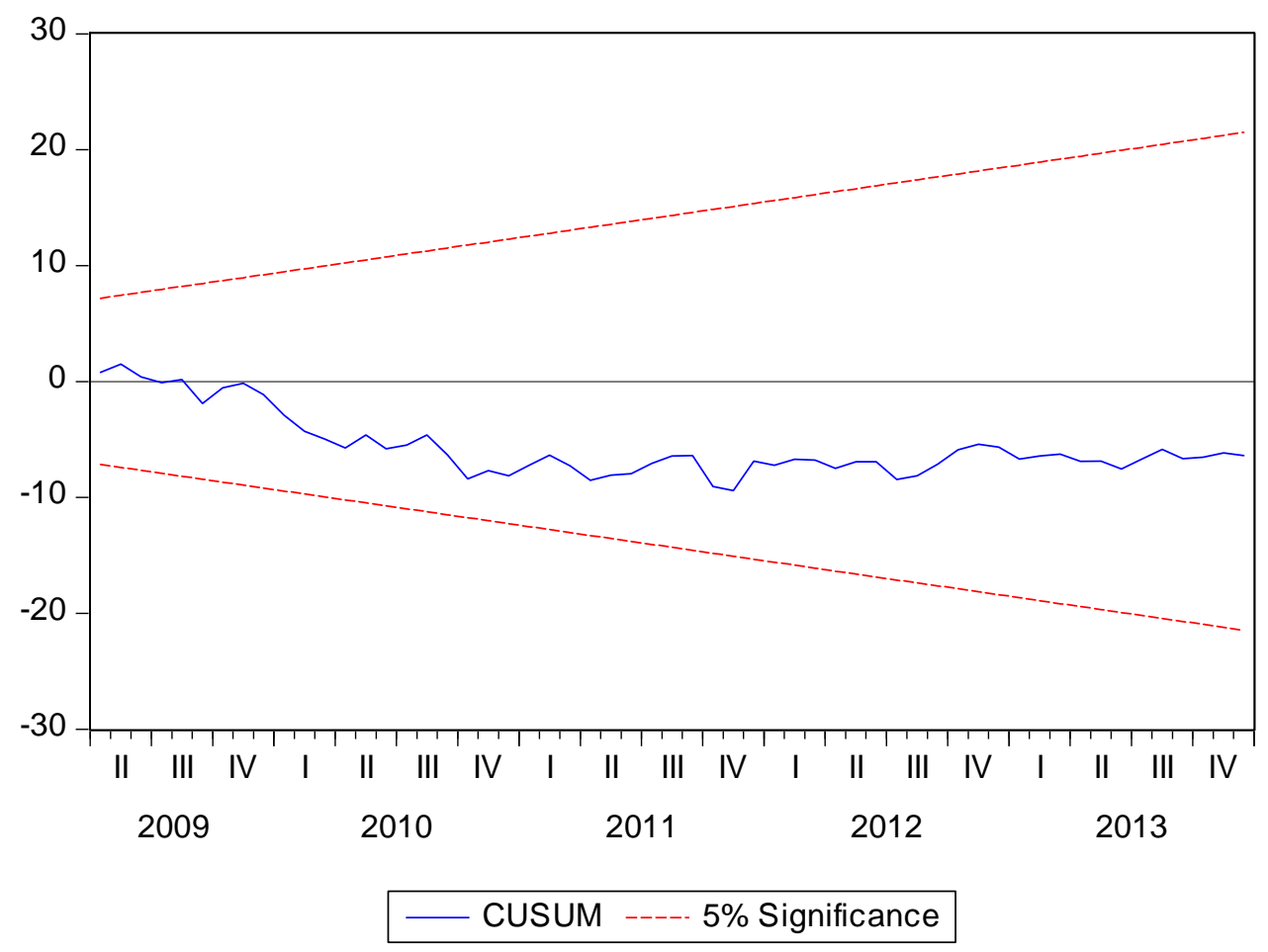

Figure 6: CUSUMSQ Test for Model Stability for Scenario 3

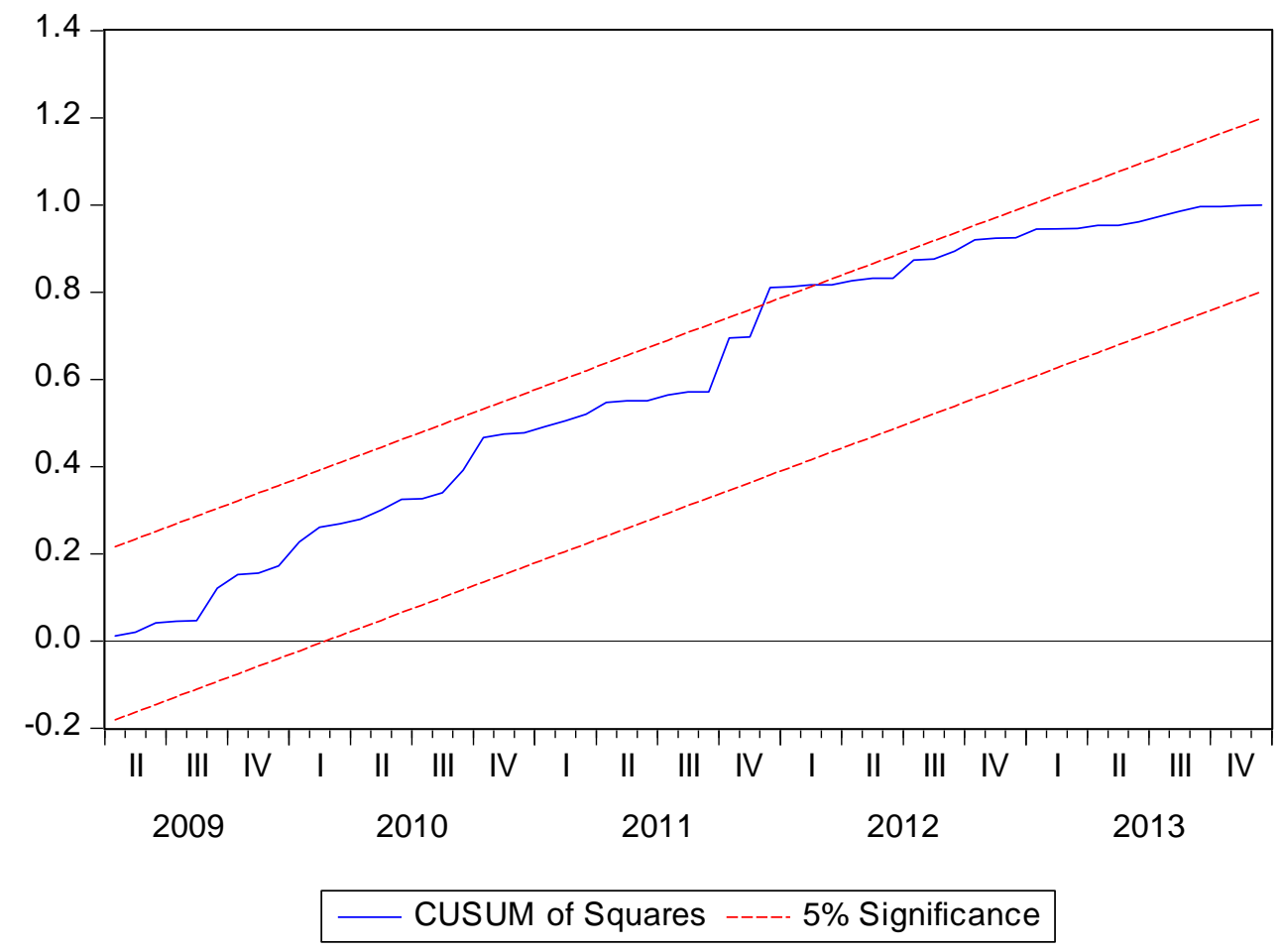


Figure 7: CUSUM Test for Model Stability for Scenario 4

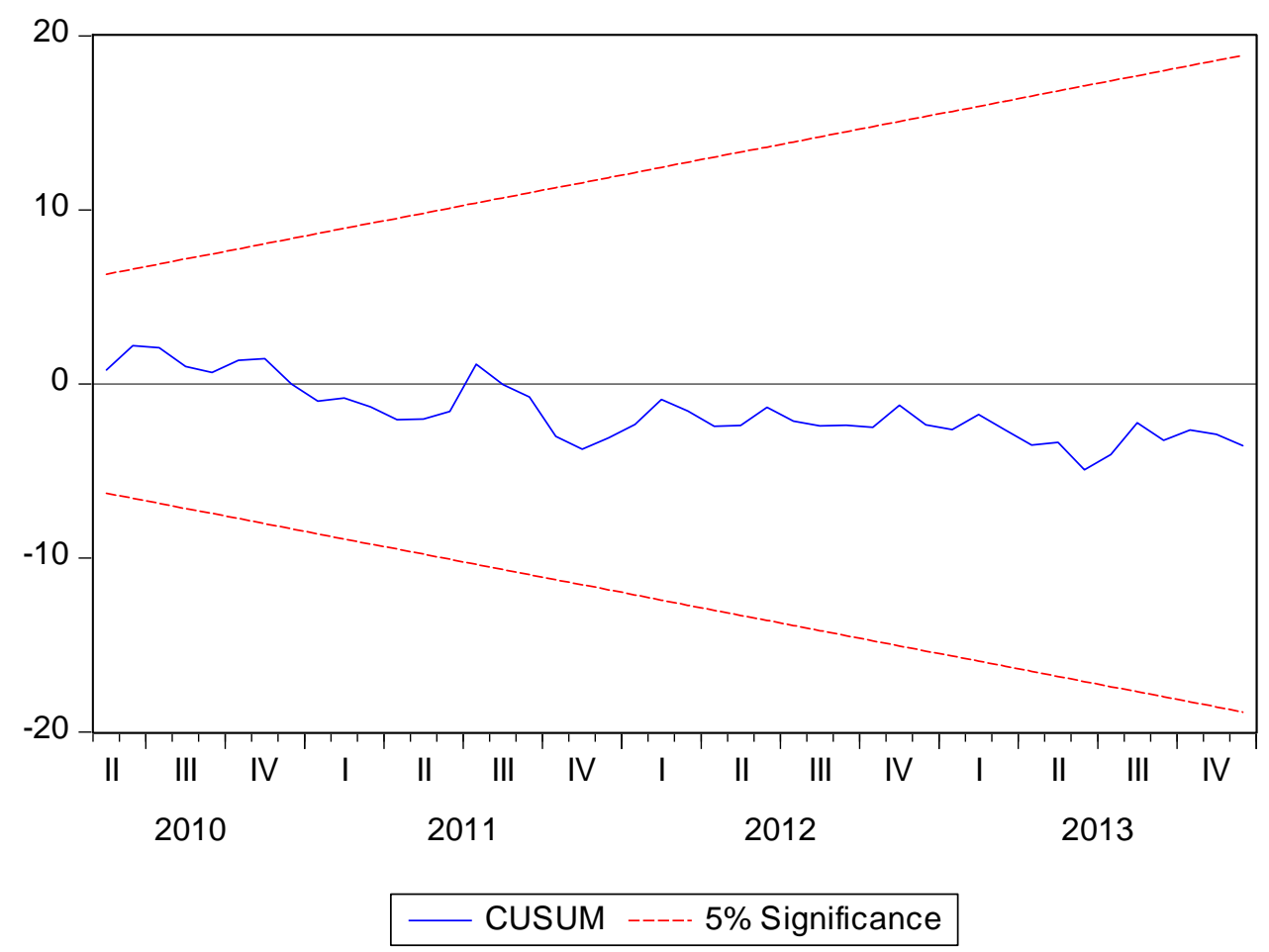

Figure 8: CUSUMSQ Test for Model Stability for Scenario 4

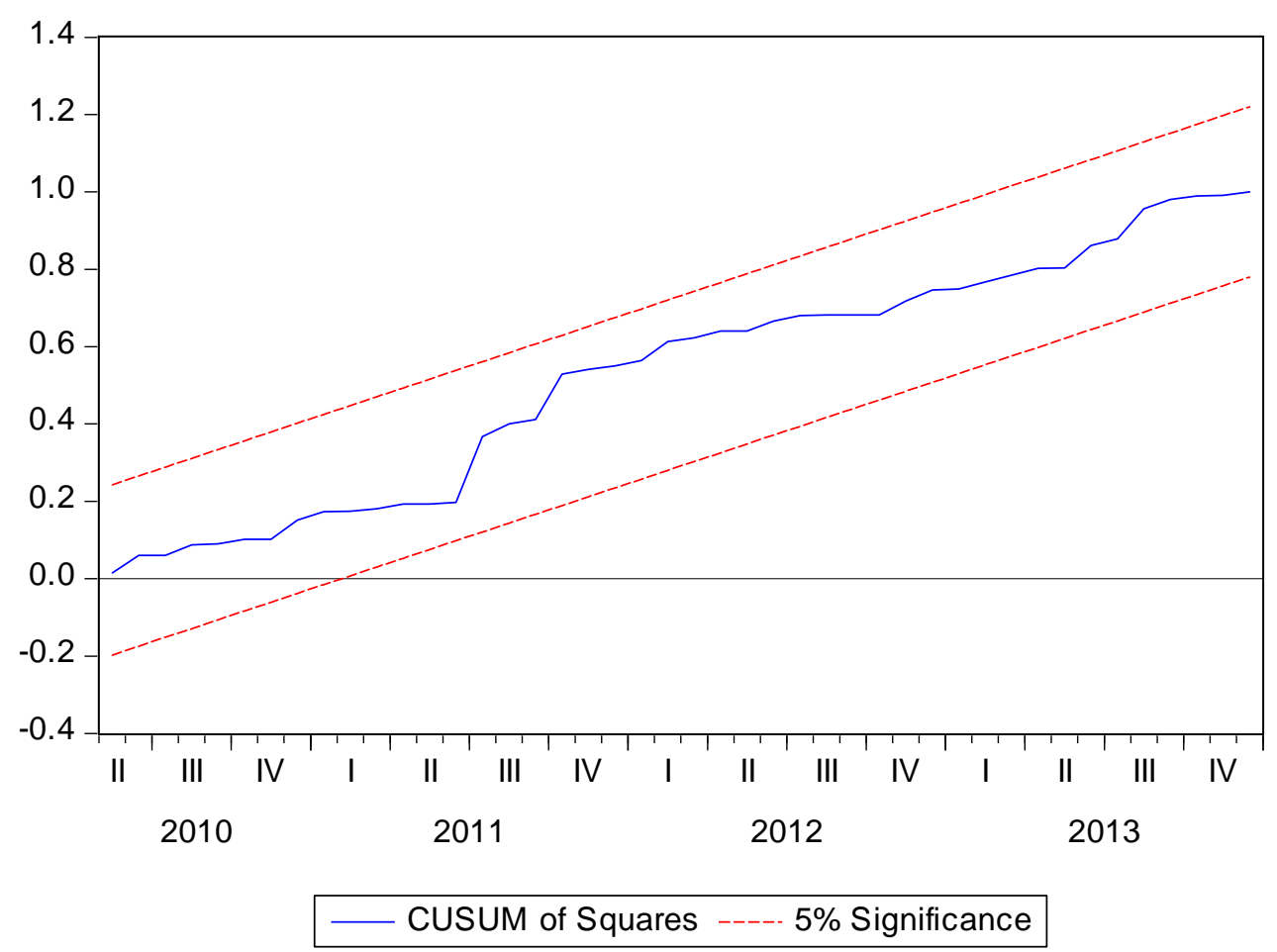




\section{Copyright Disclaimer}

2015, Vol. 7, No. 2

Copyright for this article is retained by the author(s), with first publication rights granted to the journal.

This is an open-access article distributed under the terms and conditions of the Creative Commons Attribution license (http://creativecommons.org/licenses/by/3.0/). 